Dave Mesing*

\title{
The Intervening Prince: Althusser, Foucault, and a Theory of Strategy
}

\section{Intervening in the Second Reception}

Today it has become de rigueur, especially albeit not exclusively among those of us writing within what Stefano Pippa has proposed to synthesize as Althusser's second reception, to adopt a posture of intervention, demarcating in this way a contribution towards that other Althusserian mot de passe of the conjuncture. ${ }^{1}$ Given the proliferation of this strategic couplet throughout Althusser's published and unpublished writings, such a gesture is unsurprising. Moreover, further interventions into conjunctures have also been elaborated and innovated upon by some of Althusser's closest readers and interlocutors. For example, in Can Politics Be Thought?, Alain Badiou aligns intervention with a polemical conception of politics as the rupture of the political understood as the fictive

To cite only some very recent examples in English (despite the fact extensive, innovative, and challenging Althusser scholarship has flourished in other languages and contexts), see the following introductions to special issues on Althusser: Banu Bargu and Robyn Marasco, "The Political Encounter with Louis Althusser: Introduction", Rethinking Marxism: A Journal of Economics, Culture \& Society 31 (3/2019), pp. 239-241; Stefano Pippa and Vittorio Morfino, "Reading Althusser, Again”, Revista Filosofia de la Universidad de Costa Rica 58 (152/2019), pp. 11-14. My focus and reference-point in this essay remains the Althusserian context, but I would emphasize that a strategic, interventionist approach is by no means some exclusive property among Althusser scholars. Barnard E. Harcourt, for example, has recently underscored the efforts of Walter Benjamin and Bertolt Brecht to establish a journal they titled Krisis und Kritik as well as Kritische Blätter, noting that “'Interventionist thinking' was the order of the day [and] 'inconsequential thought' was to be avoided.” Bernard E. Harcourt, “Counter-Critical Theory: An Intervention in Contemporary Critical Thought and Practice”, Critical Times: Interventions in Global Critical Theory 1 (1/2018), p. 7. Harcourt both excavates this interventionist inheritance in Benjamin and Brecht's plans as well as mobilizes it in the present towards what he calls "counter-critical theory." Benjamin and Brecht's journal title was reanimated for the 2014 launch of Crisis \& Critique by the Dialectical Materialism Collective, which has published several essays involving Althusser. 
bond between State and civil society. ${ }^{2}$ Writing from a distinct but not entirely antagonistic perspective, Étienne Balibar also has recourse to a multifaceted sense of intervention which is perhaps more imbued with the Marxian critique of political economy, ${ }^{3}$ in turn adopting intervention as an object of analysis, ${ }^{4}$ but also and more basically in the way I invoke here, as a self-description of the theoretical enterprise. ${ }^{5}$

As a multifaceted rhetorical and conceptual device, intervention and its dyadic companion conjuncture often indicate a strategic orientation which foregrounds specific context, historical inscription, a shifting balance of forces, and a kind of tentative yet aggressive experimentation captured in the Napoleonic slogan on s'engage et puis on voit - first we engage the enemy and then we see what sticks or does not stick. ${ }^{6}$ Such a strategic orientation is perhaps succinctly captured,

2 Alain Badiou, Can Politics Be Thought?, trans. Bruno Bosteels, Duke University Press, Durham, NC 2018, p. 36.

3 Étienne Balibar, "Critique in the $21^{\text {st }}$ Century: Political economy still, and religion again”, Radical Philosophy 200 (2016), pp. 11-21. For an important analysis of Badiou in this regard, see Gavin Walker, “On Marxism's Field of Operation: Badiou and the Critique of Political Economy”, Historical Materialism 20 (2/2012), pp. 39-74.

4 Étienne Balibar, "Politics and Truth: The Vacillation of Ideology, II”, in Masses, Classes, Ideas: Studies on Politics and Philosophy Before and After Marx, trans. James Swenson, Routledge, London 1994, p. 168. This sense is particularly suggestive of a critical point that should not be too quickly dispensed with, but which I can only gesture to here for reasons of space, namely that intervention has been one of the central legal, economic, political, and military practices of the state in recent decades. Balibar claims that economics is the main area of state intervention into social practice. A study of the histories and practices of intervention is sorely needed for those who adopt the theoretical posture of intervention. For a perspective generated by a critical reading of Foucault on some of the questions which arise when taking intervention as object of analysis rather than theoretical modality, see Jessica Whyte, "Human rights: confronting governments?: Michel Foucault and the right to intervene”, in M. Stone, I. Wall, and C. Douzinas (eds.), New Critical Legal Thinking: Law and the Political, Routledge, London 2012, pp. 11-31.

5 One among other examples of this, characteristically for Balibar as well as Althusser, concerns Spinoza, whom Balibar presents as composing the Theologico-Political Treatise "as a direct intervention in the political conjuncture of the crisis of the [Dutch] Republic.” Étienne Balibar, “Spinoza: The Anti-Orwell”, in Masses, Classes, Ideas: Studies on Politics and Philosophy Before and After Marx, trans. James Swenson, Routledge, London 1994, p. 9.

6 I follow Warren Montag in noting this phrase, which he uses in order to synthesize "strategy for Althusser" in terms of his philosophical interventions which were coupled with extensive reflections on the surrounding theoretical (philosophical as well as scientific) conjuncture. See Warren Montag, Althusser and His Contemporaries: Philosophy's Perpetual 
without recourse to the intervention-conjuncture dyad, in Michel Foucault's formulation of a "conceptualization [which] implies critical thought-a constant checking."7 And yet to invoke Foucault here as one possible crystallizer of such strategic theoretical practice suggests a further question, which hopefully does not open onto an infinite regress: what does it mean to intervene among friends (or enemies) concerning the status of intervening into the conjuncture?

In what follows, I present a theory of political strategy not merely as the self-contained formula "intervention into a conjuncture," but rather with further reference to the surrounding conceptual contexts of intervention, conjuncture, and other terms as a part of Althusser's philosophical lexicon. By means of a critical confrontation between some of Althusser's later writings and certain strategic formulations in Foucault, I sketch an account of strategy as the anticipation of an encounter which modifies, abolishes, or otherwise alters the relations constituting its conjuncture. To borrow Warren Montag's ambivalent deployment, Foucault is certainly best approached in this way as among Althusser's philosophical contemporaries, rather than simply a friend or enemy. Yet in some of Foucault's writing, we find a productive set of assumptions which enable the further elaboration of the intervention-conjuncture dyad in order to offer an account of strategy absent in both Foucault and, at least explicitly, Althusser. In other words, by proposing a definition of strategy as a reflection on the intervention-conjuncture dyad, I will traverse through Foucault's writings as those of an eminently strategic thinker in order to sharpen them by turning to Althusser as offering a philosophy for strategy, in addition to his own conception and lifelong project of offering a philosophy for Marxism. ${ }^{8}$

In order to propose a definition of strategy as part of the Althusserian lexicon, it is useful to tarry further with Pippa's remarks concerning Althusser's ongoing second reception, which allow me to isolate a protocol for staging a narrow

War, Duke University Press, Durham, NC 2013, p. 4. Invoking the question of engagement as another strategic modality opens up a line of inquiry into Althusser and Sartre, among others.

7 Michel Foucault, "The Subject and Power," in J. Faubion (ed.), The Essential Works of Foucault Vol. 3: Power, The New Press, New York 2000, p. 327.

8 For a succinct description as well as enactment of Althusser's distinction between philosophy for and philosophy of Marxism, see Jason Read, The Politics of Transindividuality, Haymarket Books, Chicago 2018, pp. 1-16, especially pp. 6-7. 
Althusser-Foucault encounter vis-à-vis the alternative between strategy and strategic thought. ${ }^{9}$ With his proposal of Althusser's second reception, Pippa calls attention to a tidal wave of posthumously published material, which has in part animated renewed interest in Althusser's writings, a flourishing set of debates only possible to capture in brief snapshots here. ${ }^{10}$ As he points out, since Althusser's death in 1990, “over 5,000 pages of notes, quasi-finished texts almost ready for publication, an autobiography, [and] letters" have all been published, "opening up an entirely new perspective in Althusser's scholarship."

Pippa's key anchorage point lies with the empirical fact that this enormous amount of material calls for a reconsideration of Althusser's philosophical production. However, in terms of the helpful periodization of a second reception, Pippa's insight does not only stabilize this empirical shift for those working in light of Althusser's concepts and problematics. To this first observation concerning the productive eruption of posthumously published writings, we can add two further starting points for a second reception of Althusser which are helpful in approaching an alternative between strategy and strategic thought by reading Althusser together with Foucault.

9 I stress the narrowness of this encounter, hoping it proves productive for those thinking in light of problems shared by Foucault and Althusser. For reasons of space I have been unable to enter into the complex discussions and utilizations of Foucault's methodologies, instead trying to situate a narrow set of assumptions observable in his arguments against the context of Althusser's philosophy for strategy. For one debate on methodological questions, see Colin Koopman, "Historical Critique or Transcendental Critique in Foucault: Two Kantian Lineages”, Foucault Studies 8 (February 2010), pp. 100-121; Kevin Thompson, "Response to Colin Koopman's 'Historical Critique or Transcendental Critique in Foucault: Two Kantian Lineages”, Foucault Studies 8 (February 2010), pp. 122-128; and Colin McQuillan, "Transcendental Philosophy and Critical Philosophy in Kant and Foucault: Response to Colin Koopman”, Foucault Studies 9 (September 2010), pp. 145-155. For a Foucauldian perspective closer to the Althusserian one I delineate here, see Johanna Oksala, “Foucault's Politicization of Ontology", Continental Philosophy Review 43 (November 2010), pp. 445-466. For a helpful and more expansive contrast between Foucault and Althusser throughout the 1960 s and 1970s, see Andrew Ryder, "Foucault and Althusser," Foucault Studies 16 (September 2013), pp. 134-153.

10 Below I discuss an "early" reassessment-type text by Vittorio Morfino. Another "early" text in this regard which might be useful to revisit for those working in the second reception is Maria Turchetto, “I ‘due Marx' e l'althusserismo,” in R. Bellofiore (ed.), Da Marx a Marx? Un bilancio dei marxismi italiani del Novecento, Manifestolibri, Rome 2007, pp. 101-107.

${ }_{11}$ Stefano Pippa, Althusser and Contingency, Mimesis International, Milan 2019, p. 17. 
First, Pippa convincingly demonstrates the way that the second reception of Althusser's writings has helped introduce distance from a prevailing position among earlier scholars that Althusser abandoned a faith in Marxist science in order to embrace a philosophy of contingency as the theoretical manifestation of political despair. Pippa's work is to date the most extensive treatment of the category of contingency throughout Althusser's writings, and in providing such a thorough analysis, his advancement of the second reception does not exemplify that this shift constitutes only the refusal of such rigid demarcation of distinct Althusserian stages, but rather that this reception has helped to overcome such a position. Indeed, we can find proof of this overcoming by attending to some contributions within the second reception by scholars who have labored within Anglophone Althusser scholarship prior to Pippa's proposed indexing of the second reception to the mid-to-late 1990s, such as Warren Montag's helpful discussion of the "early" appearance of the concept of encounter. ${ }^{12}$ Or, to borrow from Panagiotis Sotiris' formulation, by stepping back from an internal assessment of Althusser's variegated theoretical production, the critical, polemical, and appreciative attention Althusser has received from consecutive waves of Marxist scholars should give permanent pause to any neat typography of Althusser's structuralist phase, irrationalist phase, and so on as we continue to debate Althusser's contributions and relevance in the present. ${ }^{13}$

12 Montag, Althusser and His Contemporaries, p. 188. Indeed, in suggesting we have arrived at a second reception, Pippa rightly notes Montag's similar assessment in an article published in 1998, which I will return to later. For one elaboration of this position concerning a break in Althusser, see Antonio Negri, "Notes on the Evolution of the Thought of Louis Althusser", trans. Olga Vasile, in A. Callari and D. Ruccio (eds.), Postmodern Marxism and the Future of Marxist Theory: Essays in the Althusserian Tradition, Wesleyan University Press, Hanover, NH 1995, pp. 51-68.

13 Panagiotis Sotiris, A Philosophy for Communism: Rethinking Althusser, Brill, Leiden 2020, p. 529. Sotiris provides an extensive discussion of Althusser's entire career in a text which will undoubtedly be debated at much length in the years to come. In part three of the book especially, he undertakes a reading of Althusser's intellectual production as a continuous intervention in the context of the communist movement and what would eventually come to be called the crisis of Marxism. Moreover, he situates Althusser's entire work with regard to various strategies within this context. I offer an approach to strategy in this essay which is distinct from these nuanced and important problems synthesized well by Sotiris, which I hope is useful for revisiting these lessons throughout Althusser's work in further detail than I am able to accomplish here. 
In addition to the quantitative avalanche of posthumously published writings and the refusal of a break or discrete periods in favor of the continued elaboration of problems, a third and perhaps most relevant aspect Pippa outlines as part of the second reception concerns Althusser's status, from the beginning to end of his work, as a philosopher. To focus too narrowly on the delimitation of the philosophical enterprise, a vexed question, ${ }^{14}$ would take us too far afield, but the simple fact that Althusser's theoretical labor is animated by an engagement with classical philosophers as well as his contemporaries who undertook similar engagements in their own fashion, is important to recall. Notably, as Montag underscores in a manner which reinforces Pippa's proposal of a second reception, in terms of the Anglophone scholarship concerning French philosophers during Althusser's time, too often there has been a silo effect of thinkers such as Foucault, Derrida, and Deleuze, despite the similarities in questions among them. More importantly, I would suggest, is that each silo was indexed to a tradition: "Foucault to French epistemology, Derrida to phenomenology and Heidegger, Deleuze to Bergsonianiam, and, of course, Althusser to Marxism," such that we witness the unfortunate and unproductive appearance of monstrous groups such as Foucauldians, Derrideans, Deleuzeans, and Althusserians. ${ }^{15}$

Pippa's deployment of a second reception of Althusser is likely best understood as a heuristic starting point rather than a rigid break within intellectual history, but I take these three elements within his work and the work of other contemporary scholars as decisive touchstones for my intervention concerning intervention in what follows. Situating ourselves within this second reception allows for the possibility of new insights and problems. It is in this sense that I would

14 In light of the context I will turn to in my discussion of Althusser's "Lenin and Philosophy" address in part three, one especially technical elaboration of this question is the work of François Laruelle. An important and understudied development of this theme in Althusser's work is Paulin Hountondji, "The Myth of Spontaneous Philosophy”, Conséquence 1 (1974), pp. 11-37. I am thankful to Dhruv Jain for bringing this text to my attention. I have addressed some of the details in Laruelle's enterprise with respect to Althusser's conception of philosophy in Dave Mesing, "Critical Theory as Theoretical Practice: Althusserianism in Laruelle and Adorno,” in R. Gangle and J. Greve (eds.), Superpositions: Laruelle and the Humanities, Rowman \& Littlefield International, London 2017, pp. 59-74.

15 Montag, Althusser and His Contemporaries, p. 8. For an illuminating discussion of Althusser and French historical epistemology, see David Maruzzella, "The Two Bachelards of Louis Althusser”, Parrhesia: A Journal of Critical Philosophy 31 (2019), pp. 174-206. 
like to stage an encounter between Althusser and Foucault by traversing some of the latter's writings which show Foucault practicing a strategic thought, in order to contrast them with a definition of strategy as part of an Althusserian philosophical lexicon. In using such a protocol, I follow what I take to be an exemplary and, within the second reception of Althusser, "early" text by Vittorio Morfino, in which he emphasizes focusing on concepts, categories, and their functions in order to clarify a lexicon of terms ${ }^{16}{ }^{1}$ With reference to the intervention-conjuncture nexus, I will sketch an account of strategy as the anticipation of an encounter which modifies, abolishes, or otherwise alters the relations constituting a conjuncture. I will illuminate this theory of strategy by means of a critical contrast to a set of assumptions within Foucault's theoretical practice of strategic thought, to which we can now turn.

\section{Foucault's Strategic Priority}

In part four of La Volonté de savoir, Foucault advances a number of general propositions concerning objective, method, domain, as well as some provisional periodizations about power, particularly in light of his investigation into the history of sexuality. Despite the fact that throughout his project, Foucault presents analyses of power relations in a number of contexts, his comments in this section provide a helpful condensation of assumptions observable in his theoretical practice of strategic thought. ${ }^{17}$ One other locus of this practice, which offers a helpful way into these assumptions, is the following programmatic remark in an interview he gave in 1975, one year prior to the publication of this text. Asked to expand upon his preceding comments about making visible the unseen by changing a level, by "addressing oneself to a layer of material which

16 Vittorio Morfino, “An Althusserian Lexicon,” trans. Jason Smith, borderlands e-journal, 4 (2/2005). Available at: http://www.borderlands.net.au/vol4no2_2005/morfino_lexicon. $\mathrm{htm}$. Note that the text was originally published in 2000 as an introduction to the Italian translation of some of Althusser's late writings.

${ }_{17}$ In this context I focus on the question of Foucault's understanding of strategy and what I call his strategic priority in light of the way he invokes strategic rhetoric. Foucault's assessment of power, especially his criticisms of moralizing notions of power, are especially relevant for further debates about strategy and the history of strategy. In order to focus on drawing out a particular approach to strategy as strategic priority, I leave these substantive aspects of the context of his writings on power to one side for reasons of space. I am thankful to Asad Haider for bringing this point to my attention. 
had hitherto no pertinence for history and which had not been recognised as having any moral, aesthetic, political or historical value," Foucault responds:

Mechanisms of power in general have never been studied much by history. History has been studied by those who held power - anecdotal histories of kings and generals; contrasted with this there has been the history of economic processes and infrastructures. Again, distinct from this, we have had histories of institutions, of what has been viewed as a superstructural level in relation to the economy. But power in its strategies [le pouvoir dans ses stratégies], at once general and detailed [à la fois générales et fines], and its mechanisms, has never been studied. ${ }^{18}$

Here Foucault offers a clear statement of his strategic priority: in order to track the layer of power within the archives where it has as yet received no history, it is necessary to conduct analyses of a plurality of power relations within a plurality of contexts, thereby making visible, by means of conceptualization and a nuanced, constant checking, that "the exercise of power itself creates and causes to emerge new objects of knowledge and accumulates new bodies of information." ${ }^{19}$ In other words, analyses of power uncover power-knowledge relations by attending to strategies as the mechanisms of power. Such mechanisms come from everywhere. "One needs to be nominalistic, no doubt: power is not an institution, and not a structure; neither is it a certain strength we are endowed with; it is the name that one attributes to a complex strategical situation [une situation stratégique complexe] in a particular society." ${ }^{20}$ Here Foucault has identified the "general" as opposed to the "detailed" of power in its strategies, namely, a complex strategical situation. Should a strategist press for further clarification, Foucault continues: "perhaps we should postulate rather that this multiplicity of force relations [multiplicité des rapports de force] can be coded-in part but never totally-either in the form of 'war', or in the form of 'politics'; this would

18 Michel Foucault, "Prison Talk," in C. Gordon (ed.), Power/Knowledge: Selected Interviews \& Other Writings 1972-1977, Pantheon Books, New York 1980, pp. 50-51. The original is reprinted as Michel Foucault, “Les jeux du pouvoir,” in D. Grisoni (ed.), Politiques de la Philosophie, Grasset, Paris 1976, pp. 155-174.

19 Ibid., p. 51.

20 Michel Foucault, The History of Sexuality Volume 1: An Introduction, trans. Robert Hurley, Pantheon Books, New York 1978, p. 93. All references are checked against the original. Cf. Michel Foucault, Histoire de la sexualité I: La volonté de savoir, Éditions Gallimard, Paris 1976. 
imply two different strategies [deux stratégies differentes] (but the one always liable to switch into the other) for integrating these unbalanced, heterogenous, unstable, and tense force relations." ${ }^{21}$ Hence in being nominalistic in order to pursue the task of analyzing power mechanisms, we have an ambivalently articulated general level of strategies as war and politics, understood as integrating forms of force relations, always capable of tilting into one another.

Accordingly, Foucault's strategic priority describes both the orientation and enactment of his theoretical practice as a strategic thought into the history of mechanisms of power, on the one hand, and a postulate subtending his other assumptions about this practice throughout this part of La Volonté de savoir, on the other: there are strategies, but no strategy. In order to speak of strategy, we must do so heuristically, granting a kind of paradoxical, logical priority to the strategic over strategy. Strategy is but one tool in the arsenal of the strategic thinker in search of the mechanisms of power suffused everywhere throughout history.

By carefully attending to a number of passages in this part of La Volonté de savoir, we can observe three related assumptions Foucault makes in pursuing his strategic priority. First, as Foucault clarifies in a manner that presents more specifically how to go about writing the history of power he broaches in the interview, it is necessary to develop "an analytics" [une anaytique] of power in order to displace what he calls "a theory" [une théorie] of power, understood as the juridico-discursive representation of power. ${ }^{22}$ Foucault maps out a series of "principal features" of this theory of power, but what is most important to notice for understanding his strategic priority is his claim animating the turn towards an analytics of power: "The analysis, made in terms of power, must not assume that the sovereignty of the state, the form of the law, or the over-all unity of a domination are given at the outset; rather, these are only the terminal forms [les formes terminales] power takes." ${ }^{23}$ In other words, for Foucault, a theory of power oriented around these forms-elsewhere, he fleshes them out by referring to overlapping conceptual problems such as "right and violence, law and ille-

\footnotetext{
${ }^{21}$ Ibid.

22 Ibid., p. 82.

23 Ibid., p. 92. My emphasis.
} 
gality, freedom and will, and especially the state and sovereignty"24-implicitly renders static the actual mechanisms of power at work throughout history.

Turning to analyze power mechanisms without the structuring mediation of such a theory of power, Foucault wagers, opens up entirely new vistas. Most notably as far as strategies are concerned, an analytics of power uncovers power otherwise than under the guise of its terminal forms taken as its final word, instead allowing power as "the moving substrate of force relations [le socle mouvant des rapports de force] which, by virtue of their inequality, constantly engender [such] states of power," ${ }^{25}$ to flare up before our eyes. Hence Foucault's displacement of theory for analytics enables a conception of power which "one must first understand as the multiplicity of force relations immanent in the sphere in which they operate and which constitute their own organization." ${ }^{26}$ It is in this context of presenting a series of equivocal descriptions of such "primary" force relations that Foucault draws closest to specifying an account of strategy. In addition to the imperative to first attend to an immanent multiplicity of force relations, he adds:

[Power must be understood as] the process which, through ceaseless struggles and confrontations, transforms, strengthens, or reverses [force relations]; as the support which these force relations find in one another, thus forming a chain or a system, or on the contrary, the disjunctions and contradictions which isolate them from one another; and lastly, as the strategies [les stratégies] in which [these force relations] take effect, whose general design or institutional crystallization is embodied in the state apparatus, in the formulation of the law, in the various social hegemonies. ${ }^{27}$

As such, in addition to Foucault's first assumption concerning the methodology of analytics as opposed to theory, we witness the second: force relations as the omnipresence of power, understood dynamically as always in motion and coming from everywhere, "produced from one moment to the next, at every point,

\footnotetext{
24 Ibid., p. 89.

25 Ibid., p. 93.

26 Ibid., p. 92. Translation modified. Interestingly, Robert Hurley's translation renders the initial phrase as "in the first instance."

27 Ibid., pp. 92-93.
} 
or rather in every relation from one point to another." ${ }^{28}$ This second assumption concerning the omnipresence of power and its linear production expressed in relations effectively involves a more detailed elaboration of Foucault's claim we examined earlier concerning the necessity to "be nominalistic" in examining power mechanisms. An analytics of power uncovers a complex strategical situation coded as politics and/or war.

Foucault's third assumption in these passages allows us to begin grasping how force relations as expressed in strategies which circulate within the state apparatus, law, and social hegemony are actually composed. Whereas the "general" level of strategies reveals itself as the Janus-faced complex strategical situation of war-politics, at the more detailed level of strategies in their effectuation, we find Foucault conceiving of strategies as the agglomeration of tactical instances. It is perhaps here where Foucault's strategic priority is most rooted, so to speak. ${ }^{29}$ Indeed, such an agglomeration of tactics appears to be the result of Foucault's methodological displacement of theory into analytics: the complex strategical situation, qua moving substrate of force relations constantly engendering states of power such as the state, law, or domination which "are always local and unstable [locaux et instables]." ${ }^{\circ 0}$ As Foucault suggests in probably one of his most well-known phrases, "where there is power, there is resistance, and yet, or rather consequently, this resistance is never in a position of exteriority in relation to power." ${ }^{11}$ In light of what I have argued is Foucault's strategic priority, we can read this summary proposition of Foucault's claims throughout this section as both an expression of the major advantage gained from an analytics of power and as what enables us to make sense of Foucault's remarks which align strategies and tactics by means of formulating strategies, always and necessar-

28 Ibid., p. 93. In light of this assumption, the relationship between power and relation would be useful to study further. Foucault draws near in a few formulations to what Vittorio Morfino has called the primacy of relations, to which my account of strategy is indebted. See Vittorio Morfino, “Spinoza: An Ontology of Relation”, trans. Jason E. Smith in Plural Temporality: Transindividuality and the Aleatory Between Spinoza and Althusser, Brill, Leiden 2014, pp. 46-71.

29 Perhaps this is why some suggest Foucault provides an analysis of tactics but not strategy. For a reading of Foucault which moves in this direction by supplementing his arguments with Michel de Certeau, see Claire Colebrook, "Certeau and Foucault: Tactics and Strategic Essentialism”, The South Atlantic Quarterly, 100 (2/2001), pp. 543-574.

3o Foucault, The History of Sexuality Volume 1, p. 93.

31 Ibid., p. 95. 
ily in the plural, as ultimately comprised of particular tactical instances of the exercise of power.

Foucault develops this sense of strategies as the agglomeration of tactics in the summary proposition prior to his remark about the coterminous existence of power and resistance by claiming that "power relations are both intentional and nonsubjective." ${ }^{2}$ Arising from everywhere, no power arrives without being fixed to aims or objectives. However, the rationality of this power is displaced to level of tactics, understood as particular instances of decision-making with regard to power, out of which arises the general level of power as complex strategical situation.

[L]et us not look for the headquarters that presides over [power's] rationality; neither the caste which governs, nor the groups which control the state apparatus, nor those who make the most important economic decisions direct the entire network of power that functions in society (and makes it function); the rationality of power is characterized by tactics that are often quite explicit at the restricted level where they are inscribed (the local cynicism of power), tactics which, becoming connected to one another, attracting and propagating one another, but finding their base of support and their condition elsewhere, end by forming comprehensive systems: the logic is perfectly clear, the aims decipherable, and yet it is often the case that no one is there to have invented them, and few who can be said to have formulated them: an implicit characteristic of the great anonymous, almost unspoken strategies [des grandes stratégies anonymes] which coordinate the loquacious tactics whose 'inventors' or decisionmakers are often without hypocrisy. ${ }^{33}$

Hence, by using analytics, we uncover the mechanisms of power relations which arise everywhere from local tactics. These tactics provide, by means of becoming concatenated to one another, the basis for strategies which comprise a moving substrate of force relations.

Accordingly, one of the crucial implications of Foucault's shift to analytics, as expressed in the well-known passage about power and resistance, is that he provides the tools for a method capable of attending to a plurality of resist-

\footnotetext{
$32 \quad$ Ibid., p. 94.

33 Ibid., p. 95.
} 
ances without end. Yet Foucault punctuates these remarks with a curious and indecipherable comment on Machiavelli, which I will revisit in light of turning to Althusser in the next section. Falling back onto the received wisdom of Machiavelli as a scandalous cynic about power, ${ }^{34}$ Foucault grants his importance for conceiving "the power of the Prince in terms of relations of force," but adds, "perhaps we need to go one step further, do without the persona of the Prince, and decipher power mechanisms on the basis of a strategy that is immanent in relations of force [une stratégie immanente aux rapports de force]." ${ }_{35}$ And yet as we have observed in attending to Foucault's comments about strategies throughout this section, Foucault's analytics of power actually forestalls this question, suggesting instead that we need to take a step back rather than a step forward ${ }^{36}$ In terms of Foucault's strategic priority expressed throughout his innovative analyses in these remarks on power relations, we can analyze strategies but never strategy. ${ }^{37}$ We can uncover a complex strategical situation

34 For an alternative perspective which directs careful attention to the theoretical work of the people in Machiavelli’s writing, see Stefano Visentin, “The Different Faces of the People: On Machiavelli's Political Topography”, in F. Lucchese, F. Frosini, and V. Morfino (eds.), The Radical Machiavelli: Politics, Philosophy, and Language, Brill, Leiden 2015 pp., 368-389. Foucault, The History of Sexuality Volume 1, p. 97. Translation modified.

36 In an entirely different context, such a need to step back in order to ask the question of strategy was also broached by Gayatri Spivak in relation to the transmutation of her phrase "strategic use of positivist essentialism" into the watchword "strategic essentialism." I discuss the reference and related texts in Dave Mesing, "From Structuralism to Points of Rupture: George Jackson and the Tactics of the Subject”, Symposium: Canadian Journal of Continental Philosophy 23 (1/2019), pp. 123-125.

37 In an interview with Roger Pol-Droit published in Le Monde in February 1975, on the occasion of the publication of Discipline and Punish, Foucault makes some brief comments which further illuminate some of the assumptions I have tracked here and perhaps open up further lines of inquiry for a more thorough consideration of his writings on these questions. Responding to the question of whether he has a method, Foucault insists on abandoning the search for a system's "unconscious," instead proposing to be both more "modest and more prying [plus modeste et plus fureteur]." When studying the "mass of documents that constitute the actual discourse of political action" for the bourgeoisie, Foucault claims, we find "an absolutely conscious, organized, and reflexive strategy [une stratégie absolument consciente, organisée, réfléchie]." We must thereby substitute a logic of unconscious with a logic of strategy. Foucault thus seems to align strategy with bourgeois thought in its wielding of power, and in terms of his own proposal towards counter-strategy or counter-power, adopts the register of discrete struggles rather than strategy or strategies, proposing (likely in reference to his famous interview with Deleuze from three years earlier) that his books may be "little toolboxes [petites boites à outils]" capable of finding a use in these struggles. See Michel Foucault "Des supplices aux cellules", in 
or attend to the local in order to observe the agglomeration of detailed tactics as what comprises anonymous and nonsubjective strategic obstacles, but we can never truly ask after strategy. Foucault's strategic priority hence conceals the possibility of approaching the question of strategy as part of a concerted nexus of theory and practice in a specific conjuncture, a concealment that I will suggest can be overturned by displacing this strategic priority by moving towards a theory of strategy.

\section{Theory and the Tasks of Strategy}

A number of potential avenues for conducting a narrow Foucault-Althusser encounter are possible,,$^{38}$ but one illuminating point of contrast which will enable us to move towards an account of strategy as part of an Althusserian lexicon concerns the philosophical position of nominalism and the distinct manner in which Foucault and Althusser inhabit it. Such a contrast enables us to take a step back from Foucault's strategic priority in order to develop the suggestive possibility of strategy as intervention into conjuncture into a proposal for defining strategy as the anticipation of an encounter which will modify, abolish, or otherwise alter the relations constitutive of the conjuncture. As such, I turn to nominalism not as some eternal possibility within philosophia perennis-an idealist perspective on philosophy that Althusser and Foucault would reject in their own fashion-but rather to illuminate and produce a definition of strategy as a reflection on the intervention-conjuncture dyad, thereby allowing me to draw out some further consequences about these concepts and their functions as part of a philosophy for strategy.

D. Defert and F. Ewald (eds.), Dits et écrits tome II (1970-1975), Éditions Gallimard, Paris 1994, pp. 716-720.

38 For one example of a productive encounter between Foucault and Althusser, see Banu Bargu, "Police Power: The Biopolitical State Apparatus and Differential Interpellations", Rethinking Marxism: A Journal of Economics, Culture \& Society, 31 (3/2019), pp. 291-317. Importantly, Bargu stresses that Althusser's work has been a useful starting point, but only that, for feminist and critical race theorists. I have sketched out an initial development of some arguments which are adjacent to the contrast between strategic thought and strategy I stage here, using George Jackson's work to extend the framework I sketch in relation to a dynamic understanding of tactics in Mesing, "From Structuralism to Points of Rupture", pp. 131-137. 
As I have broached a few times, Foucault's invocation of nominalism in the context of enacting his strategic priority as an inquiry into power relations is presented in the form of an injunction: "One needs to be nominalistic, no doubt [Il faut sans doute être nominaliste]." 39 Foucault does not clarify what he means in this context, beyond the implicit suggestion that rather than fix the name of power to or as an institution, structure, strength, or capacity, "it is the name that one attributes [c'est le nom qu'on prête] to a complex strategical situation in a particular society."${ }^{.00}$ In an essay of decisive importance on Foucault and Marx, Balibar suggests that Foucault's work represents a form of nominalism in which he simultaneously carries out a break with Marxism as theory at a global level while partially using Marxist tenets or claims which are compatible with some in the Marxist tradition. ${ }^{41}$ At such a global or general level of his analyses, Balibar points out, Foucault questions "the concept of 'social relations', or contradiction as a structure internal to power relations." ${ }^{.22}$ As part of this questioning, Foucault practices a "historical nominalism" in order to make notions such as power or contradiction impossible as idealized concepts. Starting from a sense of materiality linked to the apparatus and practice of power on bodies rather than the materiality of social relations, Foucault's nominalism not only takes the form of refusing an abstract essence for such notions, but also "forbids one to pass directly from the material nature of bodies to the ideal nature of life."133 In other words, Foucault's injunction to "be nominalistic" expresses both a rejection of Marx's historical materialism and its emphasis on contradiction as well as a sort of structural similarity to the usage made of nominalism as a necessary theoretical supplement for materialism against metaphysics, which describes its deployment in Althusser's Marxian practice of philosophy.

39 Foucault, The History of Sexuality Volume 1, p. 93.

$4^{0}$ Ibid. One proposal for how to typologize Foucault's rhetorical usage of such terms is provided by Colin Koopman and Tomas Matza, who suggest that "central philosophical debates into which Foucault is often drafted," such as "nominalism versus universalism," be understood as "doctrines of philosophy", meaning that Foucault only raises the specter of such an "-ism” for rhetorical effect. Colin Koopman and Tomas Matza, "Putting Foucault to Work: Analytic and Concept in Foucaultian Inquiry”, Critical Inquiry 39 (4/2013), pp. 822-823.

41 Étienne Balibar, "Foucault and Marx: The Question of Nominalism”, in T. Armstrong (ed. and Trans.), Michel Foucault: Philosopher, Harvester Wheatsheaf, Hemel Hampsted 1992, p. 53.

42 Ibid., p. 54. 
Balibar provides the latter description of nominalism as a synthetic suggestion that both Marx and Foucault practice critiques of philosophies of history, in which the question of materialism or the nature of the material is often at hand. "One might agree to call upon nominalism as a supplement to materialism necessary to stop a particular form of materiality - economic, political, or discursive from turning back into metaphysics." ${ }^{\prime \prime 4}$ As Montag points out, such supplemental use of nominalism for materialism also characterizes Althusser's brief descriptions of the term. For Montag, the insertion of a nominalist moment into materialist theorization can be captured for Althusser by that "superb phrase" of the first proposition in Wittgenstein's Tractatus Logico-Philosophicus: Die Welt ist alles, was der Fall ist. ${ }^{45}$ However, as often is the case with Althusser, a slight shift is then introduced into the citation, such that the proposition as a "fundamental thesis of nominalism" becomes, to translate the phrase into English, "there exist only cases." As such, much like Foucault's ambivalent injunction to "be nominalistic" in order to approach the specificity of power relations, Montag shows how Althusser perceives the nominalist thesis as a means for emphasizing and focusing on the singular and diverse. ${ }^{46}$ To borrow Foucault's rhetoric, both Foucault and Althusser occupy nominalist positions as part of their strategic or philosophical practice within complex strategical situations.

Of course, as should be clear at least to scholars of Althusser working within the second reception of his philosophy, one important name for a "complex strategical situation" is precisely the conjuncture. In light of the manner in which both of them introduce nominalism into their theoretical practice, one question for Foucault's work concerns whether and to what extent it is helpful for the analysis of a conjuncture. In the short section discussing power relations we focused on earlier, it is clear that the conjuncture would only comprise one among other

$44 \quad$ Ibid., p. 56.

45 Warren Montag, "Althusser's Nominalism: Structure and Singularity (1962-6)", Rethinking Marxism: A Journal of Economics, Culture \& Society 10 (3/1998), p. 68. Montag quotes interviews with Fernanda Navarro, available in English as "Philosophy and Marxism: Interviews with Fernanda Navarro, 1984-87”, trans. G.M. Goshgarian in F. Matheron and O. Corpet (eds.), Philosophy of the Encounter: Later Writings, 1978-1987, Verso, London 2006, pp. 251-289. I note Montag's attention to Althusser's "early" writings in conjunction with much later discussions with Navarro, further giving credence to Pippa's proposal regarding the second reception of Althusser and the overcoming of neatly fixed stages in favor of an elaboration of related and revisited problems.

46 Montag, “Althusser’s Nominalism”, p. 69. 
possible heuristic names for unveiling the omnipresence of power-knowledge relations. Such a strategic priority, as we have seen, forestalls the possibility of a theory of strategy understood as a concerted nexus of theory and practice as part of a specific conjuncture. In order to break with such a priority, we might rewrite Montag's Wittgensteinian illumination of Althusser's nominalism as follows: the conjuncture is all that is the case, and yet there is intervention.

This proposition enables us to shift our focus to Althusser's philosophical lexicon. As Vittorio Morfino argues, conjuncture is Althusser's way of rewriting facticity with a further elaboration. "Conjuncture names the set of material conditions within which one is compelled to think and act." ${ }^{\text {"47 }}$ As a category, conjuncture does not only rewrite facticity into another term, but rather entails at least two further claims.$^{48}$ First, conjunctures are comprised of intertwining, contradictory, and overdetermining relations. When viewed in light of Foucault's analytic of power relations, such a claim presents an Althusserian gloss on another Foucaultian nominalistic injunction, which he presents twice over in the concluding propositions we explored above: one must not suppose that there is a neatly identifiable center from which such relations emanate..$^{49}$

Second, to be precise, any reference to "the" conjuncture must be done with the recognition that such a conjuncture is only one among other conjunctures, each of which "holds" due to the sedimentation of practices expressed in its constitutive relations while also being the object of practices able to change such relations. As Morfino writes, "the conjuncture is the facticity [...] that practice

47 Morfino, "An Althusserian Lexicon".

48 A study of Althusser's nearly continuous use of the term conjuncture would make an important contribution to Althusser scholarship and contemporary political and critical theory more generally. Here I have tried to emphasize its importance as a category rather than only a concept, and it seems to me that such a distinction might be useful to pursue in light of Althusser's materialism. I follow Morfino's discussion focused on some of Althusser's later writings but note that the term appears in a nearly constant fashion throughout his work.

"One must suppose rather [Il faut plutôt supposer] than the manifold relations of force that take shape and come into play [...] are the basis for wide-ranging effects of cleavage that run through the social body as a whole. [...] there is no power that is exercised without a series of aims and objectives. But this does not mean that it results from the choice or decision of an individual subject; let us not look [ne cherchons pas] for the headquarters [l'état-major] that presides over its rationality". Foucault, The History of Sexuality Volume 1, pp. 94-95. 
confronts, and practice is in turn possible only within the interstices of this facticity, since it can only intervene within the relations that constitute practice in the first place." ${ }^{\circ 0}$ As a category, conjuncture thus invokes what we might call the thesis of relational entwinement without center or simple contradiction, on the one hand, and the thesis of practical plurality and transformative possibility, on the other.

As apparent in attending to Morfino's brief elaboration of conjuncture as a part of Althusser's philosophical lexicon, attending to the function of this category in Althusser's arguments requires invoking the notion of intervention, perhaps not surprisingly given my repeated insistence on the intervention-conjuncture nexus as a strategic dyad, or as I have now proposed to reflect on it, the proposition that the conjuncture is all that is the case, and yet there is intervention. Morfino does not discuss intervention as a part of Althusser's lexicon, and as thorough readers of Althusser could suspect, one reason for this absence may be that, at least for a certain tendency within Althusser's continual unfolding and elaboration of his philosophical problems, intervention constitutes much less a specific part of the lexicon than the modality in which such a lexicon is expressed. By attending briefly to the question of intervention in Althusser's philosophy, we will be able to return to Foucault's refusal of the Prince and its relevance for taking a step back from his strategic priority in order to propose a theory of strategy.

Within Althusser's second reception, an important theme is the continued development of problems, or perhaps even more sharply put, the at-times continuous and at-times discontinuous clarification of a conjunctural conceptual lexicon. The notion of intervention is crucial for drawing out such a reading of Althusser's philosophical enterprise and what I propose to call his philosophy for strategy, which entails the recognition of further questions and problems which he only began to broach as a part of his own conjunctural deployments of a conceptual lexicon. Sorting out a comprehensive reading of Althusser in this regard would be beyond the scope of the present argument, but an analysis of

50 Morfino, “An Althusserian Lexicon”. An important question, which can only be briefly broached in this context, concerns distinguishing between conjunctures. This question would need to take on both the problem of the different determinations of the category or concept of conjuncture, as well as issues in space and, in my view especially, time. 
intervention in the 1968 "Lenin and Philosophy" lecture in light of some of his reflections on a continuous, strategic companion in Machiavelli will enable us to sketch such a proposal and put it to work in developing a notion of strategy as an implicit part of such a lexicon in the sense of pushing further the intervention-conjuncture dyad in order to stipulate a theory of strategy rather than only a strategic practice of thought.

As is well-known, Althusser's lecture scandalously proposes an extended reflection on Lenin in relation to philosophy for the Société Française de Philosophie, opening with a kind of provocation that the idea of a philosophical communication would have made Lenin laugh, "with that whole-hearted, open laugh by which the fishermen of Capri recognized him as one of their kind and on their side." ${ }_{51}^{1}$ Such a provocation attempts to impress upon the audience, or even enact, Lenin's response to an invitation from Maxim Gorky to discuss philosophy with a small group of Russian intellectuals. Regarding Lenin's laughter, Althusser proposes the following: "To be sure, [laughing as a refusal to philosophically discuss] was a tactical attitude: since political unity among Bolshevik émigrés was essential, they should not be divided by a philosophical dispute." ${ }^{2}$ However, Althusser suggestively continues:

We can discern in this tactic much more than a tactic [beaucoup plus qu'une tactique], something I should like to call a 'practice' [pratique] of philosophy, and the consciousness of what practicing philosophy means; in short the consciousness of the ruthless, primary fact that philosophy divides, and it can only unite by dividing. We can thus understand Lenin's laughter: there is no such thing as philosophical communication, no such thing as philosophical discussion. All I want to do today is to comment on that laughter, which is a thesis itself. ${ }^{53}$

51 Louis Althusser, "Lenin and Philosophy", in Lenin and Philosophy and Other Essays, trans. Ben Brewster, Monthly Review Press, New York 1971, p. 23. Louis Althusser, Lénine et la philosophie, François Maspero, Paris 1969. Althusser was verbally reprimanded by Jean Wahl towards the beginning of his talk, choosing not to publish this reprimand in the publication of the text of his address. See the editorial notes in Louis Althusser, Solitude de Machiavel et autres textes, PUF, Paris 1998, p. 138. I am thankful to David Maruzzella for reminding me of these details.

52 Althusser, "Lenin and Philosophy”, p. 26.

53 Ibid. My emphasis. 
Althusser links this polemical conception of philosophical practice directly to the notion of intervention, arguing that "Lenin thus defines the ultimate essence [l'essence ultime] of philosophical practice as an intervention in the theoretical domain [intervention dans le domaine théorique]. ${ }^{54}$ For Althusser, Leninist philosophical intervention simultaneously operates theoretically by formulating categories, and practically "in the function [pratique par la fonction] of these categories," or as I have attempted to reiterate here, via the clarification and demarcation of a conjunctural conceptual lexicon.

To translate Althusser's remarks in the "Lenin and Philosophy" essay in this manner and submit the notion of intervention itself to a conjunctural determination requires a brief study of Althusser's reflections on Machiavelli, the conjunctural thinker par excellence. In a manner recalling the Wittgensteinian proposition I introduced above, Althusser posits that "Machiavelli is the first theorist of the conjuncture [le premier théoricien de la conjoncture]. ${ }^{55}$ However, he then makes a decisive remark for understanding the sense in which a philosophical lexicon which includes strategy as part of its conceptual contribution can only be understood as an initial definition, subject to additional clarification and development. Althusser claims that Machiavelli is a "theorist" of the conjuncture in the sense of "if not to think the concept of conjuncture [concept de conjoncture] [...] then at least consistently - in an insistent, extremely profound way - to think in the conjuncture [pensé dans la conjoncture]: that is to say, in its concept of an aleatory, singular case [cas singulier aléatorie]. ${ }^{{ }^{6} 6}$ In terms of understanding Althusser's theoretical enterprise as a philosophy for strategy, then, his extensive study of Machiavelli is absolutely decisive. Althusser's concepts and categories, especially intervention and conjuncture, may help to establish a more elaborate, conceptual definition of strategy, but we must trace this philosophical functioning of a lexicon to, at least in Althusser's case, a close study of Machiavelli's conjunctural theory and practice as expressed in The Prince and other texts. To reformulate this tension another way, we might say that although Althusser's philosophical, conceptual lexicon helps stage a theory of strategy, it is Machiavelli who, in his theory and practice as a theorist,

54 Ibid., p. 61.

55 Louis Althusser, Machiavelli and Us, trans. Gregory Elliot, Verso, London 1999, p. 18. Louis Althusser, “Machiavelli et Nous (1972-1986)", in F. Matheron (ed.), Écrits Philosophiques et Politiques Tome II, Stock/IMEC, Paris 1995, pp. 39-168.

56 Ibid. Althusser's emphasis. 
and, we should add, practitioner in the conjuncture, truly lets us observe the functioning of strategy in his works. ${ }^{57}$

And yet, we should not run ahead of ourselves, especially given the need we have uncovered to step back from strategic prioritization in Foucault. If intervention is merely the modality of Althusser's conjunctural conceptual lexicon, we must still address whether intervention can be understood as a distinct concept helping to illuminate the definition of strategy I propose. Much like conjuncture, which I only quickly reflected on above, such a task would be helpful for pushing further into the nuances and possible counter-tendencies of the insights I have attempted to stipulate here. However, it is the question of intervention that I think the contrast with Foucault usefully illuminates, again involving Machiavelli’s Prince.

As I noted at the end of the previous section, Foucault punctuates his remarks in which he practices a strategic priority with a puzzling comment on Machiavelli's Prince. Entangled perhaps with the omnipresence of force relations, Foucault proposes an acknowledgement that Machiavelli's cynical scandal towards power makes him "among the few" to conceive the power of the Prince as in terms of force relations. He then adds: "perhaps we need to go one step further, do without the persona of the Prince, and decipher power mechanisms on the basis of a strategy that is immanent in force relations. ${ }^{.58}$ Reading Foucault to the letter, however, would seem to suggest we will always be in search of such a strategy absent from his strategic practice of analyzing power relations. Althusser and especially Machiavelli might propose the following rejoinder: rather than seek to decipher [déchiffrer] power relations, a theory of strategy proposes, and in turn takes all of its force from such a proposal, to intervene into power relations for the sake of modifying, abolishing, or otherwise altering them.

Such a displacement of Foucault thus enables us to step back from his strategic priority in order to sketch a theory of strategy. However, in putting to work such a notion, category, or concept of intervention, such a theory of strategy needs to

57 The same could be said for Lenin, and I might add that such a suggestion could be a helpful starting point for trying to work out a theory of strategy in light of Lenin's theory and practice - something which, to my knowledge is absent from his writings at an explicit level, though codified within Stalin's Foundations of Leninism. 
go beyond merely the repeated insistence within Althusser, for different contexts and concepts within his theoretical archive, that strategy might be abbreviated as intervention into a conjuncture. For we know that interventions into conjunctures do not come with guarantees. Indeed, Althusser's reading of Machiavelli attempts to enact and reflect upon this necessity of theory and practice submitted to the exigency of class struggle. As a concluding gloss on the theory of strategy we have proposed, then, in light of this narrow Foucault-Althusser encounter and its implications, we might propose the following, quasi-Wittgensteinian proposition of a Strategōs Logico-Philosophicus: conjunctures are all that is the case, and yet there is intervention-and, thankfully, encounter.

$$
n: s
$$

Although my reading of Foucault has been for the sake of illuminating the possibility of introducing strategy as a part of an Althusserian lexicon, I have attempted to suggest that they share a strategic theoretical practice whose encounter is quite productive, presenting my intervention concerning intervention as something capable of introducing new insights and problems for present and future conjunctures. To this end I would like to conclude by drawing out some additional consequences of this narrow Foucault-Althusser encounter.

First, intervention-conjuncture is indeed best understood as a strategic couplet, which extends beyond the narrow confines of Althusser and his interlocutors and critics. From the vantage of a theory of strategy, such a dyad is only strategic insofar as we propose encounter as a mediating term which inscribes the necessity of contingency, i.e., the dialectical gesture of political practice, ${ }^{59}$ into the sketch of strategy as anticipation of an encounter which modifies, abolishes, or otherwise alters the relations constitutive of its conjuncture.

Second, as Balibar has suggested, the category of conjuncture belongs to a critique of certain eschatological imaginaries imbued in various philosophies of history, expressing instead an attempt to practice philosophy in history. Despite not consistently operating with a category of conjuncture, Foucault shared in such an attempt as part of his strategic practice of thought. By intervening to propose the question of strategy polemically to Foucault's text, I have attempted

59 Sotiris, A Philosophy for Communism, p. 531. 
to demonstrate how Foucault's analyses of power relations forestall a sense of strategy as a concerted effort of theory and practice as part of an intervention into a specific conjuncture.

Yet despite some scattered indications, a similar line of attack could be taken towards what I have tried to suggest is Althusser's philosophy for strategy. Althusser often limited his strategic undertaking to the history of philosophy in a manner that proves itself immensely productive for proceeding to investigate into philosophical strategies and practices, but it must be noted that the theory of strategy I have attempted to clarify cannot remain only philosophical in its determination. As such, in order to formulate this important caveat in a manner which I think breaks with Althusser's theoretical endeavor by remaining faithful to its conceptual intervention, we must add the following claim: any theory of strategy, initially sketched as the anticipation of an encounter which will modify, abolish, or otherwise alter the relations constitutive of the conjuncture, must be developed in the way Machiavelli proceeded-not only making using of a concept or category of conjuncture, but rather submitting theory to the discipline of the conjuncture. In this sense the initial definition I have repeated should undergo a final alteration: strategy does not speculatively anticipate encounters and assess changes in the relations of "the" conjuncture, but rather its conjuncture. Strategy first and foremost as the thought of political practice requires practice in order for its further elaboration as a theoretical and practical weapon in any conjuncture.

\section{References}

Althusser, Louis, "Lenin and Philosophy", in Lenin and Philosophy and Other Essays, trans. Ben Brewster, Monthly Review Press, New York 1971

- Solitude de Machiavel et autres textes, PUF, Paris 1998

- Machiavelli and Us, trans. Gregory Elliot, Verso, London 1999

- “Machiavelli et Nous (1972-1986)", in Écrits Philosophiques et Politiques Tome II, ed. F. Matheron, Stock/IMEC, Paris 1995

Badiou, Alain, Can Politics Be Thought?, trans. Bruno Bosteels, Duke University Press, Durham, NC 2018

Balibar, Étienne, “Critique in the $21^{\text {st }}$ Century: Political economy still, and religion again”, Radical Philosophy 200 (November / December 2016).

_ "Foucault and Marx: The Question of Nominalism", in Michel Foucault: Philosopher, ed. and trans. Timothy Armstrong, Harvester Wheatsheaf, Hemel Hampsted 1992 
- "Politics and Truth: The Vacillation of Ideology, II", in Masses, Classes, Ideas: Studies on Politics and Philosophy Before and After Marx, trans. James Swenson, Routledge, London 1994

- “Spinoza: The Anti-Orwell”, in Masses, Classes, Ideas: Studies on Politics and Philosophy Before and After Marx, trans. James Swenson, Routledge, London 1994

Bargu, Banu, "Police Power: The Biopolitical State Apparatus and Differential Interpellations", Rethinking Marxism: A Journal of Economics, Culture \& Society 31 (2019), No. 3

Bargu, Banu and Marasco, Robyn, "The Political Encounter with Louis Althusser: Introduction”, Rethinking Marxism: A Journal of Economics, Culture \& Society 31 (2019), No. 3

Colebrook, Claire, “Certeau and Foucault: Tactics and Strategic Essentialism”, The South Atlantic Quarterly 100 (Spring 2001), No. 2

Foucault, Michel, “The Subject and Power”, in The Essential Works of Foucault Vol. 3: Power, ed. James Faubion, New York, The New Press, 2000

- “Des supplices aux cellules”, in Dits et écrits tome II (1970-1975), ed. Daniel Defert and François Ewald, Paris, Éditions Gallimard, 1994

- "Les jeux du pouvoir”, in Politiques de la Philosophie, ed. Dominique-Antoine Grisoni, Grasset, Paris 1976

- "Prison Talk", in Power/Knowledge: Selected Interviews \& Other Writings 1972-1977, ed. Colin Gordon, Pantheon Books, New York 1980

- The History of Sexuality Volume 1: An Introduction, trans. Robert Hurley, Pantheon Books, New York 1978

- Histoire de la sexualité I: La volonté de savoir, Éditions Gallimard, Paris 1976

Hountondji, Paulin, “The Myth of Spontaneous Philosophy”, Conséquence 1 (1974), No. 1 Koopman, Colin and Matza, Tomas, "Putting Foucault to Work: Analytic and Concept in Foucaultian Inquiry”, Critical Inquiry 39 (Summer 2013), No. 4

Maruzzella, David, “The Two Bachelards of Louis Althusser”, Parrhesia: A Journal of Critical Philosophy 31 (2019)

84 Mesing, Dave, "Critical Theory as Theoretical Practice: Althusserianism in Laruelle and Adorno”, in Superpositions: Laruelle and the Humanities, ed. Rocco Gangle and Julius Greve, Rowman \& Littlefield International, London 2017

- "From Structuralism to Points of Rupture: George Jackson and the Tactics of the Subject”. Symposium: Canadian Journal of Continental Philosophy 23 (Spring 2019), No. 1

Montag, Warren, Althusser and His Contemporaries: Philosophy's Perpetual War, Duke University Press, Durham, NC 2013

- “Althusser's Nominalism: Structure and Singularity (1962-6)", Rethinking Marxism: A Journal of Economics, Culture \& Society 10 (1998), No. 3 
- "Philosophy and Marxism: Interviews with Fernanda Navarro, 1984-87", in Philosophy of the Encounter: Later Writings, 1978-1987, ed. François Matheron and Oliver Corpet, trans. G.M. Goshgarian, Verso, London 2006

Morfino, Vittorio, “An Althusserian Lexicon”, trans. Jason Smith, Borderlands e-journal 4 (2005), No. 2, available at: http://www.borderlands.net.au/vol4no2_2005/morfino_lexicon.htm.

- “Spinoza: An Ontology of Relation”, in Plural Temporality: Transindividuality and the Aleatory Between Spinoza and Althusser, trans. Jason E. Smith, Brill, Leiden 2014

McQuillan, Colin, "Transcendental Philosophy and Critical Philosophy in Kant and Foucault: Response to Colin Koopman”, Foucault Studies 9 (September 2010).

Negri, Antonio, "Notes on the Evolution of the Thought of Louis Althusser”, in Postmodern Marxism and the Future of Marxist Theory: Essays in the Althusserian Tradition, trans. Olga Vasile, Antonio Callari and David F. Ruccio, Wesleyan University Press, Hanover 1995

Pippa, Stefano, Althusser and Contingency, Mimesis International, Milan 2019

Pippa, Stefano and Morfino, Vittorio, "Reading Althusser, Again”, Revista Filosofía de la Universidad de Costa Rica 58 (2019), No. 152

Harcourt, E. Bernard, “Counter-Critical Theory: An Intervention in Contemporary Critical Thought and Practice”, Critical Times: Interventions in Global Critical Theory 1 (April 2018), No. 1

Walker, Gavin, “On Marxism's Field of Operation: Badiou and the Critique of Political Economy”, Historical Materialism 20 (2012), No. 2

Whyte, Jessica, "Human rights: confronting governments?: Michel Foucault and the right to intervene", in New Critical Legal Thinking: Law and the Political, ed. Matthew Stone, Ilian rua Wall, and Costas Douzinas, Routledge, London 2012

Koopman, Colin, "Historical Critique or Transcendental Critique in Foucault: Two Kantian Lineages”, Foucault Studies 8 (February 2010)

Oksala, Johanna, "Foucault's Politicization of Ontology”, Continental Philosophy Review 43 (November 2010)

Read, Jason, The Politics of Transindividuality, Haymarket Books, Chicago 2018

Ryder, Andrew, "Foucault and Althusser”, Foucault Studies 16 (September 2013)

Thompson, Kevin, “Response to Colin Koopman's 'Historical Critique or Transcendental Critique in Foucault: Two Kantian Lineages”, Foucault Studies 8 (February 2010)

Turchetto, Maria, “I 'due Marx' e l'althusserismo”, in Da Marx a Marx? Un bilancio dei marxismi italiani del Novecento, ed. Ricardo Bellofiore, Manifestolibri, Rome 2007

Visentin, Stefano, “The Different Faces of the People: On Machiavelli’s Political Topography”, in The Radical Machiavelli: Politics, Philosophy, and Language, ed. Filippo Del Lucchese, Fabio Frosini, and Vittorio Morfino, Brill, Leiden 2015

Sotiris, Panagiotis, A Philosophy for Communism: Rethinking Althusser, Brill, Leiden 2020 